\title{
THE INFLUENCE KNOWLEDGE MANAGEMENT ON MARKETING PERFORMANCE
}

\author{
Ade Ilham Pratama*1, Syahputra ${ }^{2}$ \\ Universitas Telkom, Indonesia \\ Adepratamaa97@gmail.com*1
}

\begin{abstract}
FPS Famous Pacific Shipping is a company engaged in the field of the expedition which was formed in 2006, the company began with the name Internusa Hasta Buana which was founded by Mr. Iskandar Zulkarnain in 1991. Internusa Hasta Buana then gave birth to a subsidiary namely FPS Indonesia (Famous Pacific Shipping). This research aims to determine the influence of knowledge management on marketing performance at PT. FPS Indonesia. The variables used in this study are Knowledge Management (X1), and the dependent variable (Y), Marketing Performance. The research method used is a quantitative method with descriptive and causal research types. The unit of analysis is a total sample of 20 employees of PT. FPS Indonesia. The data collection method was carried out through questionnaires containing 20 valid questions. The analysis technique uses simple linear regression and the data is calculated using the SPSS program. Based on the calculation of the coefficient of determination shows a value of $59.8 \%$ which means this value indicates that the Knowledge Management variable influences Marketing Performance by $59.8 \%$ and the remaining $40.2 \%$ are influenced by variables not examined.
\end{abstract}

Keywords: Knowledge Management, Marketing Performance, FPS Indonesia

\section{INTRODUCTION}

FPS Famous Pacific Shipping is a company engaged in the field of an expedition which was formed in 2006 , the company began with the name Internusa Hasta Buana which was founded by Mr. Iskandar Zulkarnain in 1991. Internusa Hasta Buana then gave birth to a subsidiary namely FPS Indonesia (Famous Pacific Shipping). FPS Indonesia has a role as a provider of international and domestic transportation services. FPS Indonesia provides a variety of expedition services such as Ocean Freight, Air Freight services, International and domestic distribution, warehousing, and supply chain management. FPS Indonesia is included in the Global FPS Group which is formed from 43 individual companies from 21 different countries. FPS Indonesia offers several service products as a livelihood in its business, and these products are, first, forwarding services, where forwarding is the delivery of goods via water, land, and air facilities which includes export and import activities, as well as other services such as projects cargo handling. Second, Customs Broker service, which provides services for all matters related to legality and customs and excise documents. Third, Domestic service, a service that serves domestic areas around Indonesia which is very closely related to the term Trucking. Fourth, Warehousing as a temporary storage and storage service with all handling services included, for example, packaging goods and weighing goods. FPS Indonesia is located at Graha Iska, JI. Pramuka Raya no. 165. The main focus of the FPS company is to service domestic transportation activities, customs brokers, packaging providers, project cargo handling, and all activities related to managing cargo transfer. Supported by 13 branch offices spread from Medan (North Sumatra) to Mataram (East Nusa Tenggara).

Marketing performance is an achievement obtained from a comprehensive marketing process from a company or organization. Besides, marketing performance can also be used as a concept used to measure the 
extent to which market achievements have been obtained by-products manufactured by the company. (Mardiyono, 2018) explain marketing is a social and managerial process with individuals and groups obtaining what is needed and obtained by creating and exchanging products and values with each other. Marketing performance is something that is used to measure the success of strategies used by companies in marketing their products in the market (Sugiyarti \& Ardyan, 2017) Marketing performance is a construct that is commonly used to measure the impact of implementing corporate strategy (Daniel Alexander Titahena, Abdul Syukur, 2012) Nevertheless, the problem, performance measurement becomes a classic problem and solution because of development, multidimensional marketing performance in which various objectives and types of organization are included..

Table 1. Sales Data for PT. FPS Indonesia 2014-2019

\begin{tabular}{cr}
2014 & 5.579 .357 .560 \\
2015 & 6.593 .587 .120 \\
2016 & 7.784 .426 .332 \\
2017 & 6.373 .941 .932 \\
2018 & 6.399 .208 .567 \\
2019 & 3.931 .627 .957 \\
\hline Source: PT. FPS Indonesia (2020)
\end{tabular}

The table above shows the sales results of PT. Indonesian FPS during the
2014-2019 period. From the graph above it can be concluded that the sales of PT. FPS Indonesia during the 20142019 period experienced fluctuating sales, meaning that marketing performance affected the company's sales level. To get good marketing performance results also need good and effective strategies. Mature strategies are needed by companies to be able to read market opportunities and also recognize the behavior of customers, to develop effective and efficient strategies also need competent people. Therefore every employee in the company must be able to develop their respective knowledge. Based on previous research knowledge management influences marketing performance, although the impact of the influence of knowledge management is not significant. It was explained that according to (Vidović, 2010) although knowledge management is already prevalent in organizations, there is no standard framework for measuring the contribution of knowledge management to organizational performance, and there are very few studies that have been published about measuring the performance of knowledge management ( $\mathrm{Yu}$ et al., 2009).

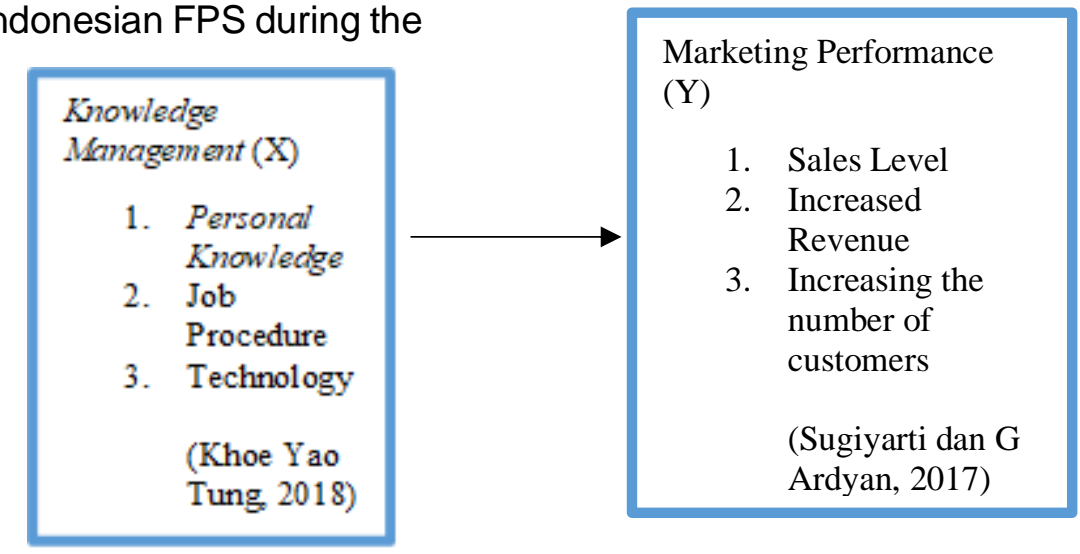

Figure 1. Framework

Source: Processed data (2020) 
Based on the framework of thought and hypothesis, the authors take a temporary decision or hypothesis in this study that "There is a Direct Effect between Knowledge Management on Marketing Performance at PT. FPS Indonesia "

\section{METHODS}

This research uses descriptive research and causality by using a quantitative approach. This research consists of two types of variables. The independent variable in this study is Knowledge Management (X), while the dependent variable is Marketing Performance $(Y)$. The measurement scale for each variable used in this study is the ordinal scale and the instrument scale is the Likert scale. The population in this study are employees who work at PT. FPS Indonesia. The sample is 20 employees at PT. FPS Indonesia. Data collection techniques were carried out through interviews and distributing questionnaires to employees at PT. FPS Indonesia, while secondary data is obtained through books, literature, articles, and websites on the internet. The data analysis technique used is descriptive analysis.

\section{RESULTS AND DISCUSSION}

Based on the results of the data processing and analysis are carried out in the previous sub-chapter. The research aims to find out how the influence of Knowledge Management on Marketing Performance at PT. FPS Indonesia. Here are the results of testing that data already completed

\section{Test Validity and Reliability}

Validity testing for the questionnaire was carried out using the Pearson Product Moment while the reliability test used Cronbach's Alpha. Both tests were carried out using SPSS Software version 25.0. Based on the results of the validity and reliability test, the statement instruments in this study were valid and reliable.

\section{Normality Test}

Based on the normality test results obtained as follows:

Table 2. Normality Test Results

\begin{tabular}{|c|c|c|}
\hline & One-Sample Kolmogorov-Smirnov Test & \\
\hline & & $\begin{array}{l}\text { Unstandardized } \\
\text { Residual }\end{array}$ \\
\hline$\overline{\mathrm{N}}$ & & 20 \\
\hline Normal Parameters ${ }^{\mathrm{a}, \mathrm{b}}$ & Mean & .0000000 \\
\hline & Std. Deviation & .36229162 \\
\hline Most Extreme Differences & Absolute & .162 \\
\hline & Positive & .097 \\
\hline & Negative & -.162 \\
\hline Test Statistic & & .162 \\
\hline Asymp. Sig. (2-tailed) & & $.180^{\circ}$ \\
\hline
\end{tabular}

a. Test distribution is Normal.

b. Calculated from data.

c. Lilliefors Significance Correction.

Source: Primary data from researchers (2020)

Based on Table 2 shows that the Asymp value. Sig. (2-tailed) is 0.18 and the value is more than the significant value (0.05), in other words, the residual variance is normally distributed.

\section{Multicollinearity Test}

Based on the multicollinearity test results obtained as follows: 
Table 3. Multicollinearity Test Result

\begin{tabular}{|c|c|c|c|c|c|c|c|}
\hline \multirow[t]{2}{*}{ Model } & \multicolumn{2}{|c|}{$\begin{array}{l}\text { Unstandardized } \\
\text { Coefficients }\end{array}$} & \multirow{2}{*}{$\begin{array}{l}\text { Standardized } \\
\text { Coefficients } \\
\text { Beta }\end{array}$} & \multirow[t]{2}{*}{$\mathrm{t}$} & \multirow[t]{2}{*}{ Sig. } & \multicolumn{2}{|l|}{$\begin{array}{l}\text { Collinearity } \\
\text { Statistics }\end{array}$} \\
\hline & B & $\begin{array}{l}\text { Std. } \\
\text { Error }\end{array}$ & & & & Tolerance & VIF \\
\hline 1 (Constant) & $\begin{array}{l}1.11 \\
1\end{array}$ & .673 & & 1.650 & .116 & & \\
\hline $\begin{array}{l}\text { Knowledge } \\
\text { Management }\end{array}$ & .747 & .144 & .773 & 5.174 & .000 & 1.000 & $\begin{array}{l}1.0 \\
00\end{array}$ \\
\hline
\end{tabular}

Source: Processed data (2020)

Based on table 3, it can be seen that the VIF value $<10$ and Tolerance $>$ 0.1 , means that no multicollinearity problem was found in this study.

\section{Heteroskedasticity Test}

Based on the multicollinearity test results obtained as follows:

Scatterplot

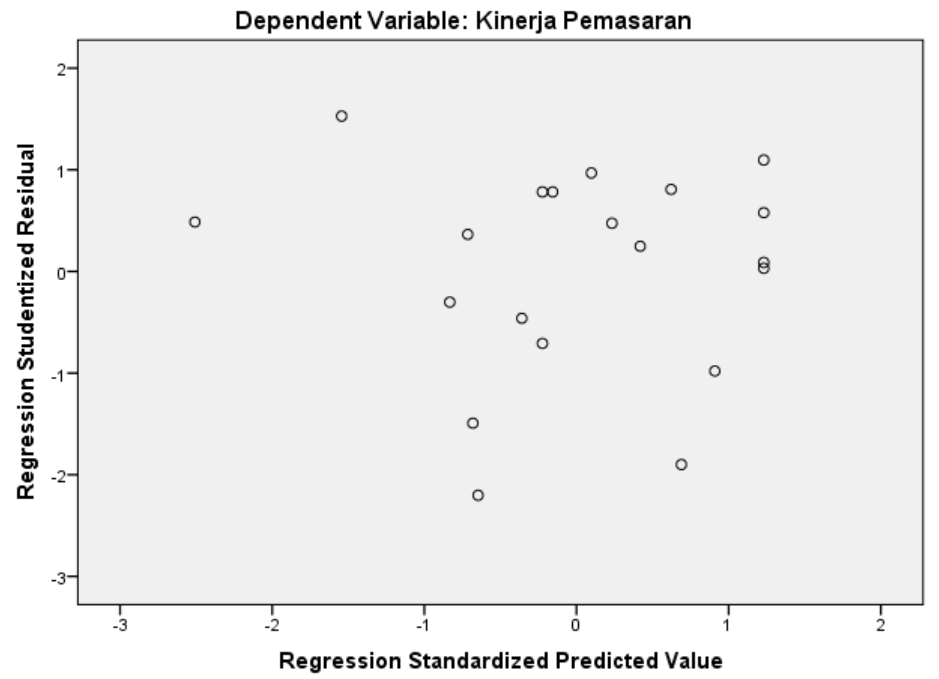

Figure 2. Heteroscedasticity Test Results

Source: Processed data (2020)

In Figure 2 it can be seen that the scatter diagram does not form a particular pattern so the regression does not experience heteroscedasticity disorder.

\section{Simple Linear Regression Analysis Results}

Simple Regression Analysis is used to determine the effect of the Independent Variables (Knowledge Management) on Bound Variables (Marketing Performance) conducted on 20 respondents of employees of PT. FPS Indonesia. 
Table 4. Simple Linear Regression Analysis

\begin{tabular}{|c|c|c|c|c|}
\hline \multicolumn{5}{|c|}{ Coefficients $^{a}$} \\
\hline Model & & \multicolumn{2}{|l|}{$\begin{array}{l}\text { Unstandardized } \\
\text { Coefficients }\end{array}$} & $\begin{array}{l}\text { Standardized Coefficients } \\
\text { Beta }\end{array}$ \\
\hline 1 & (Constant) & 1.111 & .673 & \\
\hline a. Dep & $\begin{array}{l}\text { Knowledge } \\
\text { Management } \\
\text { ndent Variable }\end{array}$ & $\begin{array}{l}.747 \\
\text { Performance }\end{array}$ & .144 & .773 \\
\hline
\end{tabular}

Source: Processed data (2020)

Based on the results of data processing in Table 4, a simple regression equation model can be formulated as follows:

$$
\begin{gathered}
Y=a+b X \\
Y=1,111+0,747 X
\end{gathered}
$$

Based on these equations can be described as follows:

a. Constants $(a)=1,111$. That is, if Knowledge Management value is 0 , then Marketing Performance is 1,111 .

b. Regression Coefficient of Marketing Performance variable (b) is positive, which is 0.747 . This means that each increase in Knowledge Management is increased by one unit, the Marketing Performance will increase by 0.747 .

\section{Partial Hypothesis Test (t-Test)}

Hypothesis testing in this study was conducted to determine the significance of the hypothesis that was formulated. Since the data analysis technique used in this study is a Simple Linear Regression, the test is only a partial Hypothesis Test (t-test).

decision-making criteria used are: (1) $t$ count $>t$ table and the significance value is less than 0.05 , then $\mathrm{HO}$ is rejected and $\mathrm{Ha}$ is accepted. This shows the significant influence of Knowledge Management on Marketing Performance; (2) t count $<t$ table and the significance value is more than 0.05 , then $\mathrm{HO}$ is accepted and $\mathrm{Ha}$ is rejected. This shows that there is no significant effect of Knowledge Management on Marketing Performance.

To determine the value of the $t$ table, it is necessary to have free degrees with the formula:

Degree of Freedom (df) $=(n-k)$ and Level of Accuracy $(\alpha)=5 \%$

$\mathrm{n}=$ Number of Samples, $\mathrm{n}=20$

$\mathrm{k}=$ Number of Variables used, $\mathrm{k}=2$

Then, Degrees of Freedom (df) $=\mathrm{n}-\mathrm{k}=20-2=18$

The t-test used is a two-way test, then the table used is t $0.05(18)=2,101$

Table 5. T-Test Results (Partial)

\begin{tabular}{rrrrrrr}
\hline & Model & \multicolumn{2}{c}{$\begin{array}{c}\text { Unstandardized } \\
\text { Coefficients } \\
\text { Std. Error }\end{array}$} & $\begin{array}{c}\text { Standardized } \\
\text { Coefficients } \\
\text { Beta }\end{array}$ & $\mathrm{t}$ & Sig. \\
\hline 1 & (Constant) & 1.111 & .673 & & 1.650 & .116 \\
& Knowledge & .747 & .144 & .773 & 5.174 & .000
\end{tabular}

Management

a. Dependent Variable: Kinerja Pemasaran

Source: Processed data (2020) 
Knowledge Management Variable (X) has t-count (5.174)> t table (2.101) and a significance level of $0.000<0.05$, then $\mathrm{HO}$ is rejected. Therefore, it can be concluded that there is a significant influence on Knowledge Management $(X)$ on Marketing Performance $(Y)$.

\section{Coefficient of Determination}

The results of the analysis of the coefficient of determination can be seen in the following table:

Table 6. Determination Coefficient Test Results

\begin{tabular}{lcccr}
\hline Model & $\mathrm{R}$ & $\begin{array}{c}\text { Model Summary } \\
\mathrm{R}\end{array}$ & $\begin{array}{c}\text { Adjusted R } \\
\text { Square }\end{array}$ & $\begin{array}{r}\text { Std. Error of } \\
\text { the Estimate }\end{array}$ \\
\hline 1 & \multicolumn{7}{c}{ Square } & Sq3 & .598 & .576 & .37222 \\
a. Predictors: (Constant), Knowledge Management \\
b. Dependent Variable: Kinerja Pemasaran \\
\multicolumn{4}{c}{ Source: Processed data (2020) }
\end{tabular}

Based on table 6 shows that the Rvalue of 0.773 and $R$ Square (R2) is 0.598 . This figure is used to see the effect of Knowledge Management. The way to calculate $\mathrm{R}$ Square using the Coefficient of Determination (KD) using the following formula:

$\mathrm{BC}=\mathrm{R}^{\wedge} 2 \times 100 \%$

$=\llbracket(0.773) \rrbracket \wedge 2 \times 100 \%$

$=59.8 \%$

This figure shows the coefficient of determination (KD) of $59.8 \%$. This shows that the influence of Independent Variables in the form of Knowledge Management amounted to $59.8 \%$ while the remaining $40.2 \%$ was influenced by other variables not examined such as Knowledge Sharing, Employee Performance, Organizational Performance, and Organizational Culture.

\section{CONCLUSION}

Based on the results of research conducted on the effect of Knowledge Management on Marketing Performance at PT. FPS Indonesia can be drawn several conclusions that are expected to provide answers to the problems formulated in this study are as follows: That the Knowledge Management (X) variable is included in the "Very Good" category with a total score of 1147 from the ideal score with a percentage of $88.23 \%$. This shows that employees at
PT. FPS Indonesia has good managerial knowledge, including understanding its duties and responsibilities, being able to think creatively and thoroughly, being able to interact with colleagues, being able to work effectively and efficiently by applicable SOPs.

That the Marketing Performance variable $(Y)$ is included in the category of "Very Good" with a total score of 593 from an ideal score with a percentage value of $84.71 \%$. This shows that there is a very good influence on customer growth, an increase in the number of customers, customer satisfaction with the services provided, marketing development by the company because of the marketing performance of PT. Good Indonesian FPS.

Effect of Knowledge Management on Marketing Performance Knowledge Management has a positive effect on the marketing performance of PT. FPS Indonesia. Knowledge Management variable has $t$ count greater than t table because $t$ count $(5,174)>t$ table $(2,101)$ and a significance level of $0,000<0.05$, then $\mathrm{HO}$ is rejected and $\mathrm{Ha}$ is accepted and it can be concluded that there is an influence of the Knowledge Management $(X)$ variable on marketing performance $(\mathrm{Y})$ at PT. FPS Indonesia. Based on the calculation of the coefficient of determination shows a value of $59.8 \%$ which means that this 
value indicates that the Knowledge Management variable influences Marketing Performance by $59.8 \%$ and the remaining $40.2 \%$ are influenced by variables not examined.

\section{REFERENCES}

Daniel Alexander Titahena, Abdul Syukur, dan S. D. U. (2012). ANALISIS PENGARUH ORIENTASI PASAR, INOVASI Daniel Alexander Titahena, Pasca Sarjana Magister Manajemen Udinus Abdul Syukur , Pasca Sarjana Magister Manajemen Udinus St . Dwiarso Utomo, Pasca Sarjana Magister Manajemen Udinus PROGRAM PASCASARJANA MAGIST. Manajemen, 21.

Mardiyono, A. (2018). Analisis Kinerja Pemasaran Usaha Kecil Menengah Di Kota Semarang. $7(1)$.

Sugiyarti, G., \& Ardyan, E. (2017). Market sensing capability and product innovation advantages in emerging markets: The case of market entry quality and marketing performance of batik industry in Indonesia. DLSU Business and Economics Review, 27(1), 175189.

Tung, Yao Khoe. (2018). Memahami Knowledge Jakarta: INDEKS.

Vidović, M. (2010). The link between the quality of knowledge management and financial performance - The case of Croatia. EFZG Working Paper Series, 03, 1-15.

Yu, W. Der, Chang, P. L., Yao, S. H., \& Liu, S. J. (2009). KVAM: Model for measuring knowledge management performance of engineering community of practice. Construction Management and Economics, 27(8), 733-747. https://doi.org/10.1080/01446190 903074978 